ORIGINAL ARTICLE

\title{
A DNA vaccine encoding p39 and sp41 of Brucella melitensis induces protective immunity in BALB/c mice
}

\author{
Una vacuna de DNA codificando proteínas p39 y sp41 de Brucella melitensis \\ induce protección inmune en ratones $\mathrm{BALB} / \mathrm{c}$
}

\author{
A Al-Mariri", R Akel, AQ Abbady
}

Department of Molecular Biology and Biotechnology, Atomic Energy Commission, Damascus, Syria.

\begin{abstract}
RESUMEN
Las especies de Brucella son bacterias gram-negativas intracelulares facultativas que pueden multiplicarse dentro células fagocíticas y no-fagocíticas en hospederos finales tanto humanos como animales. B. melitensis causa aborto en animales y fiebre ondulante en humanos. Una proteína de superficie de $41 \mathrm{kDa}$ (sp41) está asociado con la adherencia bacteriana e invasión de células HeLa. El rol de esta proteína es importante para la interacción con células hospederas. Previamente se ha descrito el antígeno inmunodominante p39, medido por células T. Ambos vectores (pCIsp41 y pCIp39) indujeron la formación de inmunoglobulinas séricas antígeno-específicas así como una respuesta proliferativa de células T y una fuerte producción de interferon gamma luego de la re-estimulación, ya sea con los antígenos específicos o con extracto de Brucella. El nivel de protección fue significativo en ratones tratados con pCIp39 y pCIsp41, pero fue inferior al nivel requerido.
\end{abstract}

Palabras claves: vacuna DNA, Brucella, proteina, protectiva.

\section{SUMMARY}

Brucella species are facultative intracellular gram-negative bacteria that can multiply within phagocytic and non-phagocytic cells of humans or animals as end hosts. B. melitensis causes abortion in pregnant animals and undulant fever in humans. A $41 \mathrm{kDa}$ surface protein (sp41) is associated with bacterial adherence and invasion of HeLa cells. The role of this protein a is important for the interaction with host cells. Previously, the putative periplasmic binding protein $\mathrm{p} 39$ had been described as T-cell immunodominant Brucella antigens. Both vectors (pCIp39 and pCIsp41) induced antigenspecific serum immunoglobulin as well as a T-cell-proliferative response and a strong gamma interferon production upon re-stimulation with either the specific antigens or Brucella extract. The level of protection was significant in pCIp39 and pCIsp41 treated mice but it was lower than the required level.

Key words: DNA vaccine, Brucella, protein, protective.

\section{INTRODUCTION}

Brucella melitensis, a facultative intracellular pathogen, is the etiological agent of brucellosis, a disease that affects humans and several other animal species (Seleem et al 2010). Infection in humans occurs through direct contact with infected animals and from ingestion of contaminated dairy products (Glynn and Lynn 2008). Furthermore, there are no human vaccines currently available (Gorvel 2008). Resistance to Brucella depends on acquired cell-mediated immunity (CMI) (Yingst and Hoover 2003). The development of Th1 subset CD4+ lymphocytes that secrete gamma interferon (IFN- $\gamma$ ), a crucial cytokine, up-regulates the macrophage anti-Brucella activity (Zhan and Cheers 1993). Denoël et al (1997 $\left.7^{\mathrm{a}, \mathrm{b}}\right)$ have previously described p39 (a putative periplasmic binding

Accepted: 06.06.2013.

* P.O. Box 6091, Damascus, Syria; ascientific@aec.org.sy protein) as T-cell immunodominant Brucella antigens that elicit both a strong delayed-type hypersensitivity reaction in guinea pigs sensitized with brucellin and in vitro proliferation or IFN- $\gamma$ production by peripheral blood mononuclear cells from infected cattle. Castañeda-Roldán et al (2006) showed that Brucella surface proteins bound selectively to HeLa cells. However, only antibodies directed against the $41 \mathrm{kDa}$ surface protein (sp41) inhibited in dose-response manner, bacterial adherence and invasion of HeLa cells (Castañeda-Roldán et al 2006). Live attenuated vaccines that can stimulate strong CMI responses are usually very effective against brucellosis (DelVecchio et al 2006). Attenuated strains such as B. melitensis Rev.1 is used to control brucellosis in domestic animals (Muñoz et al 2008). However, these are less than ideal because the vaccine strain used for animal is considered too virulent or unsafe for humans (Davis and Elzer 2002). Moreover, B. melitensis Rev.1 strain induces antibodies to their lipopolysaccharide (LPS), making it difficult to differentiate vaccinated animals from those naturally in- 
fected (Blasco 1997, Banai 2002). In order to avoid these drawbacks, alternative vaccine approaches are needed. To develop the next generation of Brucella vaccines, we are pursuing different strategies, including development of subunit vaccines (Al-Mariri et al 2001ª), immunisation with plasmid DNA encoding the protective antigen (Al-Mariri et al 2001 ${ }^{\mathrm{b}}$ ) and utilization of bacterial vectors (Al-Mariri et al 2002). DNA vaccine can stimulate both cellular and humoral immunity and provide prolonged antigen expression, leading to amplification of immune response and induce memory responses against infectious agents (Donnelly et al 1997, Kutzler and Weiner 2008). A number of studies have demonstrated that after naked DNA immunisation, the antigen is naturally processed and presented to T cells in the context of major histocompatibility complex class I and class II molecules, inducing a broad range of immune responses including antibody production and the activation of CD8+ cytotoxic T cells and CD4+ T helper cells (Higgins et al 2007, Coban et al 2008). With regard to effectiveness, previous studies have already shown that DNA vaccination with ribosomal L7/L12 (Kurar and Splitter 1997), p39 (Al-Mariri et al 2001 ${ }^{\text {}}$ ), L7/L12-p39 (Luo et al 2006a), lumazine synthase (Velikovsky et al 2002), outer membrane protein 31 gene (Vemulapalli et al 2000), BLSOmp31 (Cassataro et al 2007) and $\mathrm{Cu}-\mathrm{Zn}$ superoxide dismutase (SOD) (MuñozMontesino et al 2004) can elicit partial protection against Brucella challenge. In the present study, DNA-encoded p39 vaccine and that encoding sp41 were studied, in $\mathrm{BALB} / \mathrm{c}$ mice, in order to evaluate the immunogenicity and protective efficacy of p39 and sp41 antigens against B. melitensis infection.

\section{MATERIAL AND METHODS}

\section{ANIMALS}

Specific-pathogen-free 7 to 8 weeks-old female BALB/c purchased from Charles River Laboratories (France); were used. Three groups of 20 mice and another group of 10 mice were housed in polypropylene cages with sterilized bedding under controlled conditions; temperature $\left(24 \pm 1^{\circ} \mathrm{C}\right)$, and relative humidity $(55 \%)$; and maintained on a standard diet and sterilized water.

\section{MICROORGANISM}

B. melitensis $16 \mathrm{M}$ and vaccinated strain B. melitensis Rev.1 were obtained from the University of Namur (Belgium). Brucella was grown under optimal conditions in 2YT (peptone [10 g], sodium chloride [5 g], meat extract [5 g], distilled water [1 litre]) overnight at $37^{\circ} \mathrm{C}$ and $5 \% \mathrm{CO}_{2}$ to ensure sufficient cell density; or in 2YT-Agar (agar $[20 \mathrm{~g}]$ ), for $72 \mathrm{~h}$ at $37{ }^{\circ} \mathrm{C}$ and $5 \% \mathrm{CO}_{2}$. All experiments with live Brucella were performed in biosafety level 2 facilities. Escherichia coli strain DH5 $\alpha$ was used to prepare the plasmid constructs; whereas E. coli BL21 (DE3) was used for protein expression. The E. coli cultures were routinely grown at $37^{\circ} \mathrm{C}$ in Luria-Bertani broth or agar and were supplemented when required, with 100 $\mathrm{mg} / \mathrm{mL}$ ampicillin.

\section{CONSTRUCTION OF DNA VACCINE CANDIDATES.}

DNA fragments of the p39 and sp41 genes from $B$. melitensis $16 \mathrm{M}$ were amplified by a PCR in which the $\mathrm{XbaI}$ and EcoRI or XhoI and XbaI were ligated into the multiple-cloning site of the mammalian expression vector pCI (Promega, Madison, Wis.), giving pCIp39 and pCIsp41, respectively. The PCR primers were designed as shown in Table 1.

Large-scale plasmid DNA isolation was performed using a Plasmid Giga Kit (Qiagen, Valencia, CA) according to the manufacturer's instructions. Plasmids were finally resuspended in phosphate-buffered saline (PBS) at a concentration of $1,000 \mathrm{mg} / \mathrm{mL}$. DNA concentration and purity were determined by measuring the optical density, and the $\mathrm{A}_{260} / \mathrm{A}_{280}$ ratio was typically greater than 1.8 . The recombinant plasmid construct was verified both by restriction enzyme digest and by sequencing the complete insert.

\section{PRODUCTION OF RECOMBINANT sp41 AND p39 PROTEINS}

Expression of the Brucella p39 protein has been previously described (Al-Mariri et al 2001ª). Briefly, the respective genes (p39 and sp41) were cloned into a pET-15b expression vector and the resulting plasmid was introduced in E. coli BL21 (DE3) (Novagen, Madi-

Table 1. List of the primers used in this study.

Listado de iniciadores usados en este estudio.

\begin{tabular}{|c|c|c|c|}
\hline $\mathrm{N}$ & Names & Sequence & Base \\
\hline 1 & p39-F(XhoI) & 5'-TATGGATCCCCGGTTGCAGGTG 3'- & 22 \\
\hline 2 & p39-R(XbaI) & 5'-TAGCGGCCGCTTATTTTGCGGCTTC-3' & 25 \\
\hline 3 & sp41-F(EcoRI) & 5' - ATACACTCGAGATGTTCACCCGTCTGATCACG -3’ & 32 \\
\hline 4 & $\mathrm{sp} 41-\mathrm{R}(\mathrm{XbaI})$ & 5'-CGAGATCTAGAATTATTGAGCTGCGGCGATTG-3' & 32 \\
\hline
\end{tabular}


son, Wis.), and the positive clones were selected. The recombinant proteins were expressed in successfully transformed bacteria by induction with isopropyl- $\beta$-Dthiogalactopyranoside (IPTG) in LB medium and then purified with a Ni2-HiTrap chelating 5-mL prepacked column (Amersham Pharmacia Biotech) by using imidazole as the elution reagent, according to the manufacturer's protocol. The lysates of transformed cells and the purified protein were identified by sodium dodecyl sulfate-polyacrylamide gel electrophoresis (SDS-PAGE) and Western blot assays. The purified protein was then stored at -70 ${ }^{\circ} \mathrm{C}$ until use for enzyme-linked immunosorbent assay (ELISA) or for in vitro stimulation of splenocytes.

\section{POLYCLONAL ANTIBODIES AGAINST p39 AND sp41}

The immunisation protocol was described in detail by Kenison et al (1990). Briefly, a New Zealand white female rabbit was injected intradermally with $100 \mu \mathrm{g}$ of rp39 or rsp41 in Freund's adjuvant (complete for the initial injection; incomplete for subsequent intramuscular injections) diluted 1:1 with sterile saline. Three inoculations were performed at 2-week intervals. Antisera were collected 10 days after the last injection; antisera used in this work were used at working dilutions of 1:500.

\section{ANTIGEN EXPRESSION IN VERO CELL LINE}

Monkey kidney Vero cells were grown at $37{ }^{\circ} \mathrm{C}$ in $5 \% \mathrm{CO}_{2}$ in six-well plates (TTP, Swaziland) containing Dulbecco's modified Eagle's medium (DMEM) (Gibco, BRL) supplemented with $10 \%$ fetal bovine serum (FBS), $2 \mathrm{mM}$ L-glutamine, penicillin $(100 \mathrm{U} / \mathrm{mL})$, and gentamicin $(50 \mathrm{mg} / \mathrm{mL})$, and subconfluence monolayers were washed once with serum-free DMEM; afterwards, 500 $\mathrm{ml}$ of DMEM (supplemented as above, but without FBS) was added. Next, $100 \mathrm{ml}$ of transfection mixture (100 $\mathrm{ml}$ of serum-free DMEM containing $6 \mathrm{mg}$ of Fugene6 [Boehringer, Mannheim, Germany]) and $1 \mathrm{mg}$ of plasmid DNA were held at room temperature (RT) for $5 \mathrm{~min}$ and added to the cells, which were then incubated at $37^{\circ} \mathrm{C}$ in $5 \% \mathrm{CO}_{2}$ overnight. Expression of sp41 and p39 proteins was detected by immunoblotting.

\section{SDS-PAGE AND WESTERN BLOT ANALYSIS}

SDS-PAGE and immunoblot analysis of purified p39 and sp41proteins were performed using standard procedures. For Western blot analysis, proteins were transferred from the SDS-PAGE (12\% [wt/vol] polyacrylamide) gel to 0.2 -mm-pore-size nitrocellulose membranes (BioRad). Membranes were probed, first with 1:1000 dilution of a rabbit anti-p39 or anti-sp41 antibody that diluted in TBST (10 mM Tris-HCl, pH=8, $150 \mathrm{mM} \mathrm{NaCl,} \mathrm{0,1 \%}$ Tween 20) + 1\%BSA (serum albumin bovine, Sigma); and then with a 1:2000 dilution of goat anti-rabbit IgG conjugated to horseradish peroxidase (Bethyl Laboratories, Inc) that diluted in TBST $+1 \%$ BSA. Detection of p39 and sp41 antigens was achieved upon development with the substrate TMB (3,3,5,5-tetramethyl benzidine) (Amresco, USA) in citrate-phosphate buffer $(0.05 \mathrm{M}$ $\mathrm{Na}_{2} \mathrm{HPO}_{4}, 0.025 \mathrm{M}$ citric acid, $\mathrm{pH} 5.0$ ) and $2 \mathrm{mM} \mathrm{H}_{2} \mathrm{O}_{2}$ were added to monitor the peroxidase activity.

\section{MICE DNA VACCINATION AND CHALLENGE}

Mice randomLy allocated in three groups of 20 mice, received intramuscular (i.m.) injections in the tibialis anterior muscles with $100 \mathrm{mg}$ of a mixture of plasmids containing the p39 and sp41, in $50 \mathrm{ml}$ sterile saline (PBS), by using a $1-\mathrm{mL}$ insulin syringe with a 28 -gauge needle (Weeratna et al 2001, Oñate et al 2003). The negative control groups included one group of 20 mice immunised with $100 \mathrm{mg}$ pCI vector alone and one group of 20 mice treated with $100 \mathrm{ml}$ of saline. Three vaccinations at 3 -week intervals were performed. The immune response (five mice per group) was analysed 4 and 8 weeks after the last DNA vaccination. The fourth experimental group of mice $($ no $=10)$, which serve as positive control, was intraperitoneally received $1 \times 10^{5} \mathrm{CFU}$ of Rev. 1 in $100 \mathrm{ml}$ of sterile PBS 4 weeks before the challenge with B. melitensis 16M. For protection study, ten mice per group from the four groups were challenged i.p. with approximately $3 \times 10^{5} \mathrm{CFU}$ of $B$. melitensis $16 \mathrm{M}$ in 100 $\mathrm{ml}$ of sterile PBS, Thirty days after the last DNA injection. Whereas, for the immunisation study, ten mice per group from three groups only were sacrificed at the $4^{\text {th }}$ and $8^{\text {th }}$ weeks after the last immunisation. IgG, proliferation cells and cytokine production were analised in order to determine the immune responses.

\section{IG ELISAS}

The presence of serum IgG specific to p39 and sp41 was determined by indirect ELISA on the $4^{\text {th }}$ and $8^{\text {th }}$ weeks after the final immunisation. The wells of polystyrene plates (MaxiSorp; TPP, Swaziland) will be coated overnight at $4{ }^{\circ} \mathrm{C}$ with recombinant protein p39 or sp41 (50 $\mu \mathrm{l}$ per well) at a final concentration of $1 \mu \mathrm{g} / \mathrm{mL}$ in PBS ( $\mathrm{pH}$ 7.4) or with B. melitensis $16 \mathrm{M}$ bacterial lysate at a concentration $3 \mu \mathrm{g} / \mathrm{mL}$. After three wash cycles with PBS, the plates will be saturated for $2 \mathrm{~h}$ at RT with $150 \mu \mathrm{l}$ of blocking buffer (PBS with 2.5\% BSA). The wells will be washed with PBS containing $0.1 \%$ Tween 20 . Fifty microliters of serially twofold-diluted individual serum samples, starting at a 1/100 dilution in buffer (PBS with $1.25 \%$ BSA, 50 mM EDTA, and 0.05\% Tween 20), will be added to the plates and incubated for $1 \mathrm{~h}$ at RT. After five washing cycles, plates will be incubated with a 2,000fold dilution of IgG goat anti-mouse horseradish peroxidase conjugates (Amersham) for $1 \mathrm{~h}$ at RT. The excess reagent will be removed by five washing cycles. Finally, 
TMB (3,3,5,5-tetramethyl benzidine) in citrate-phosphate buffer $\left(0.05 \mathrm{M} \mathrm{Na}_{2} \mathrm{HPO}_{4}, 0.025 \mathrm{M}\right.$ citric acid, $\left.\mathrm{pH} 5.0\right)$ and $2 \mathrm{mM} \mathrm{H}_{2} \mathrm{O}_{2}$ will be added to monitor the peroxidase activity. The reaction is stopped after $20 \mathrm{~min}$ by addition of $2 \mathrm{M} \mathrm{H}_{2} \mathrm{SO}_{4}$. The optical density is measured at 450 and $630 \mathrm{~nm}$. The cutoff value for the assay was calculated as the mean specific OD plus standard deviation (SD) for 10 serum samples, assayed at a dilution of 1:50, from nonimmunised mice. The titer of each serum was calculated as the reciprocal of the highest serum dilution yielding a specific OD higher than the cutoff value. All assays were performed in triplicate and repeated three times.

\section{LYMPHOCYTE PROLIFERATION ASSAYS}

Spleens were homogenized with $2 \mathrm{~mL}$ of tissue culture medium (RPMI 1640-5\% fetal bovine serum; [Eurobio, Cedex, Frence]), and erythrocytes were lysed with Gey's solution. Splenocytes at $2 \times 10^{5}$ per well were stimulated with concanavalin A $(\mathrm{ConA} ; 3 \mathrm{mg} / \mathrm{mL})$, purified recombinant protein $\mathrm{p} 39$ or sp41 antigen $(1 \mathrm{mg} / \mathrm{mL})$, bacteria lysate $(4 \mathrm{mg} / \mathrm{mL})$, or no additive in culture medium for a total volume of $0.1 \mathrm{~mL}$ per well. Cell proliferation was determined in triplicate, utilized Cell Counting kit-F (ALEXIS, Biochemicals, Switzerland).

After $72 \mathrm{~h}$ of incubation at $37^{\circ} \mathrm{C}$ in $5 \% \mathrm{CO}_{2}$, the plates were three times washed D-PBS(-) to remove esterase and phenol red, then $100 \mathrm{ml}$ of D-PBS(-) was left in each well. $10 \mathrm{ml}$ of CCK-F working solution were added to each well and incubated at $37^{\circ} \mathrm{C}$ for $30 \mathrm{~min}$. The measurement of the fluorescence intensity of each well was performed at $535 \mathrm{~nm}$ (excitation at $485 \mathrm{~nm}$ ) using a fluorescence plate reader (FluoroSkan Ascent FL, ThermoElectron Corporation). The mean number of cells counts and the standard error of the mean for each triplicate of cells were also determined.

\section{MEASUREMENT OF CYTOKINES}

Spleen cell suspensions from four immunised or control mice were prepared in RPMI medium and plated at $2 \times 10^{5}$ cells/well in round-bottomed micro-well plates. The cells were stimulated in vitro with rp39 or rsp41 $(1 \mathrm{mg} / \mathrm{mL}$ each), or bacteria lysate $(4 \mathrm{mg} / \mathrm{mL})$, or with medium alone or with ConA, $3 \mathrm{mg} / \mathrm{mL}$ and incubated at $37{ }^{\circ} \mathrm{C}$ under $5 \% \mathrm{CO}_{2}$. Supernatants were taken after $72 \mathrm{~h}$ of culture, stored at $-80^{\circ} \mathrm{C}$ and assayed for cytokine production. Levels of IL-5 and IFN- $\gamma$ in culture supernatants were measured by sandwich ELISA using paired cytokine-specific mAbs (Euro-Clone, SPA, Milan, Italy), and samples of which were tested in duplicate. The concentration of IFN- $\gamma$ or IL-5 in the culture supernatants was calculated via a linear-regression equation obtained from the absorbance values of the standards as indicated by the manufacturer. Values of less than 40 and $10 \mathrm{pg} / \mathrm{mL}$ were considered negative for IFN- $\gamma$ and IL-5, respectively.

\section{PROTECTION EXPERIMENT}

Protection experiments were performed as described previously (Al-Mariri 2010). Briefly, mice were sacrificed by cervical dislocation 4 and 8 weeks after challenge with $3 \times 10^{5} \mathrm{CFU}$ of $B$. melitensis $16 \mathrm{M}$, and the spleen was removed aseptically. Each spleen was homogenized, serially diluted 10-fold and plated on 2YTagar to determine the number of Brucella CFU per spleen. Plates were incubated at $37{ }^{\circ} \mathrm{C}$ under $5 \% \mathrm{CO}_{2}$. The number of CFUs per spleen was counted after 3 days and the data were presented as the mean $\log \mathrm{CFU} \pm$ standard deviation (SD) per group. Log-units of protection were determined by subtracting the mean log CFU of the vaccinated groups from the mean $\log \mathrm{CFU}$ of the saline-immunised group.

\section{STATISTICAL ANALYSIS}

All assays were performed in triplicate, and group means were calculated. The data for lymphocyte proliferation, detection of cytokines, and protection experiments were analised by Student's paired t test.

\section{RESULTS}

\section{CONSTRUCTION AND EXPRESSION OF PCIP39 AND PCIsp41 DNA VACCINES}

pCIp39 and pCIsp41 DNA vaccines were constructed in order to studying its immune response and protective immunity against brucellosis. The recombinant plasmids were verified with restriction digestions and sequencing. Recombinant plasmids were transformed into Vero cells to verify that the constructed DNA vaccines can be expressed in mammalian cells correctly. Western blot assays of the lysate of the transformed Vero cells (figure 1) shown the presence of $39-\mathrm{kDa}$ protein and $41-\mathrm{kDa}$ protein, that corresponding to the molecular masses of p39 and sp41 respectively.

\section{HUMORAL IMMUNE RESPONSE ELICITED BY PCIp39 AND PCIsp41 IMMUNISATION}

Figure 2 revealed that pCIp39 and pCIsp41 vaccines were induced $\mathrm{IgG}$ responses to $\mathrm{p} 39, \mathrm{sp} 41$ and B. melitensis $16 \mathrm{M}$ bacterial lysate, which were 1.5 to $2 \operatorname{logs}$ higher in the group that killed 4 weeks after the last immunisation comparing with that killed 8 weeks after the last immunisation.

\section{CELLULAR IMMUNE RESPONSE OF MICE VACCINATED I.M. WITH PCIp39 AND PCIsp41}

Figure 3 shows the proliferative response and cytokine profile of splenocytes taken from mice that immunised i.m. with pCIp39+pCIsp41 DNA vaccine or with pCI. 


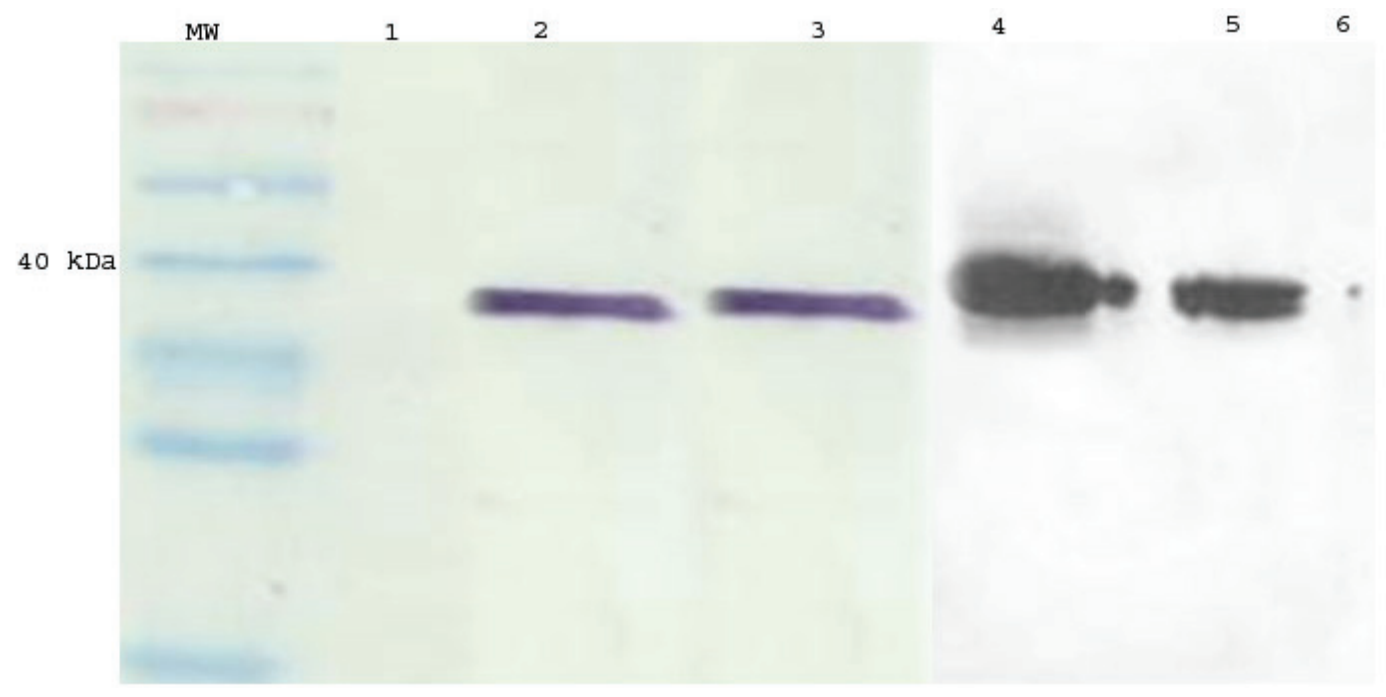

Figure 1. Expression of recombinant plasmid pCIp39 and pCIsp41 in Vero cells. The lysates of Vero cells transformed with the recombinant plasmids were analised for the respective target protein expression by Western blot assay. Vero cells were transformed with pCI (lane 1) as negative control, pCIp39 (lane 3) or pCIsp41 (lane 5). Loaded sample containing rp39 or rsp41 (0.5 $\mu$ g) were used as positive control (lanes 2 and 4 respectively). Lane (MW), molecular size protein markers.

Expresión del plasmido recombinante pCIp39 y pCIsp41 en células Vero. Los lisatos de las células Vero transformadas con los plasmidos recombinantes fueron analizados para la respectiva expresión de proteína objetivo usando el ensayo Western blot. Las células Vero fueron transformadas con pCI (carril 1) como control negativo, pCIp39 (carril 3) o pCIsp41 (carril 5). La mustra cargada conteniendo rp39 o rsp41 (0,5 $\mu$ g) fue usada como control positivo (carriles 2 y 4 respectivamente) Carril (MW), proteínas marcadoras de tamaño molecular.

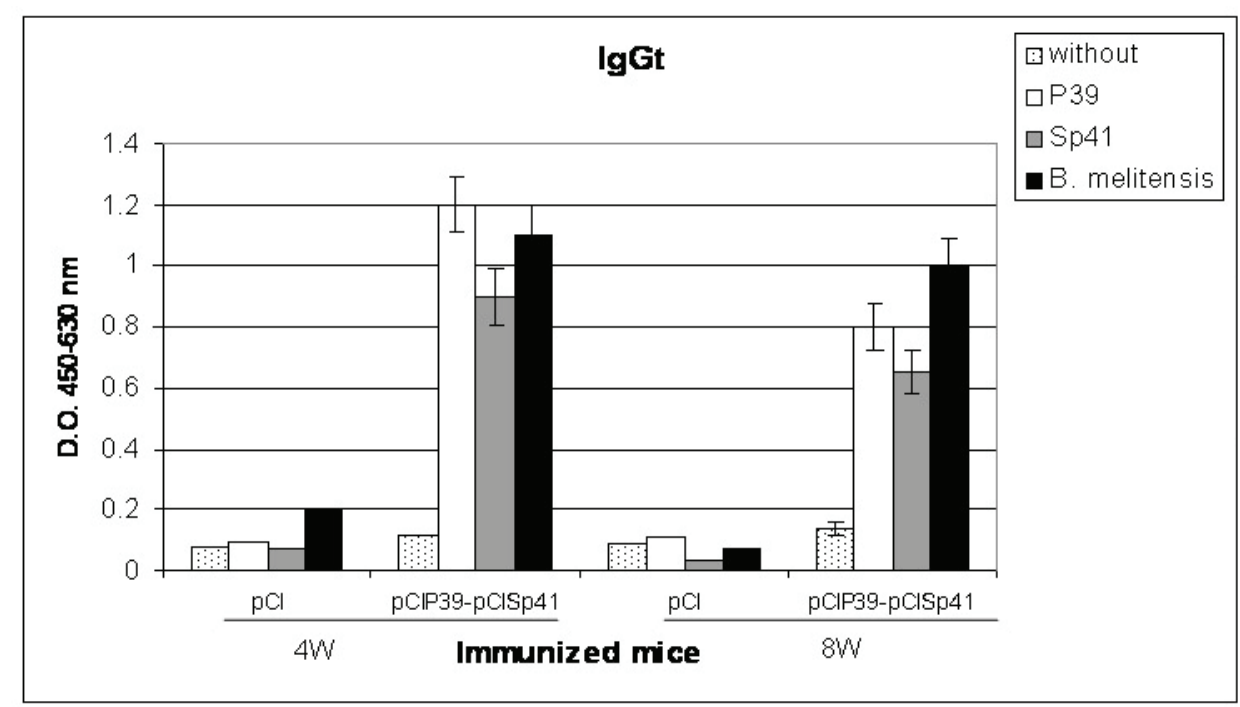

Figure 2. IgG antibody titers after immunisation with DNA vaccines for $\mathrm{p} 39$ and $\mathrm{sp} 41$. BALB/c mice (Five per group) were inoculated intramuscularly with pCIp39 and pCIsp41 DNA vaccines. Mice that received a pCI injection were negative controls. Four and eight weeks after the last immunisation, sera were collected from the experimental mice, and antibody titers were evaluated by ELISA. The optical densities were measured at 450 and $630 \mathrm{~nm}$. Data were represented the average of three independent experiments. The titer of each serum was calculated as the reciprocal of the highest serum dilution yielding a specific OD higher than the cutoff value.

Títulos de anticuerpos IgG después de la inmunización con vacunas de ADN para p39 y sp41. Ratones BALB/c (cinco por grupo) fueron inoculados por vía intramuscular con vacunas de ADN pCIp39 y pCIsp41. Los ratones que recibieron una inyección de pCI eran controles negativos. Cuatro y ocho semanas después de la última inmunización, se obtuvieron sueros de los ratones experimentales, y los títulos de anticuerpos fueron evaluados por ELISA. Las densidades ópticas se midieron a 450 y $630 \mathrm{~nm}$. Los datos representan el promedio de tres experimentos independientes. El título de cada suero se calculó como el recíproco de la mayor dilución de suero promediando un OD específico más alto que el valor de corte. 


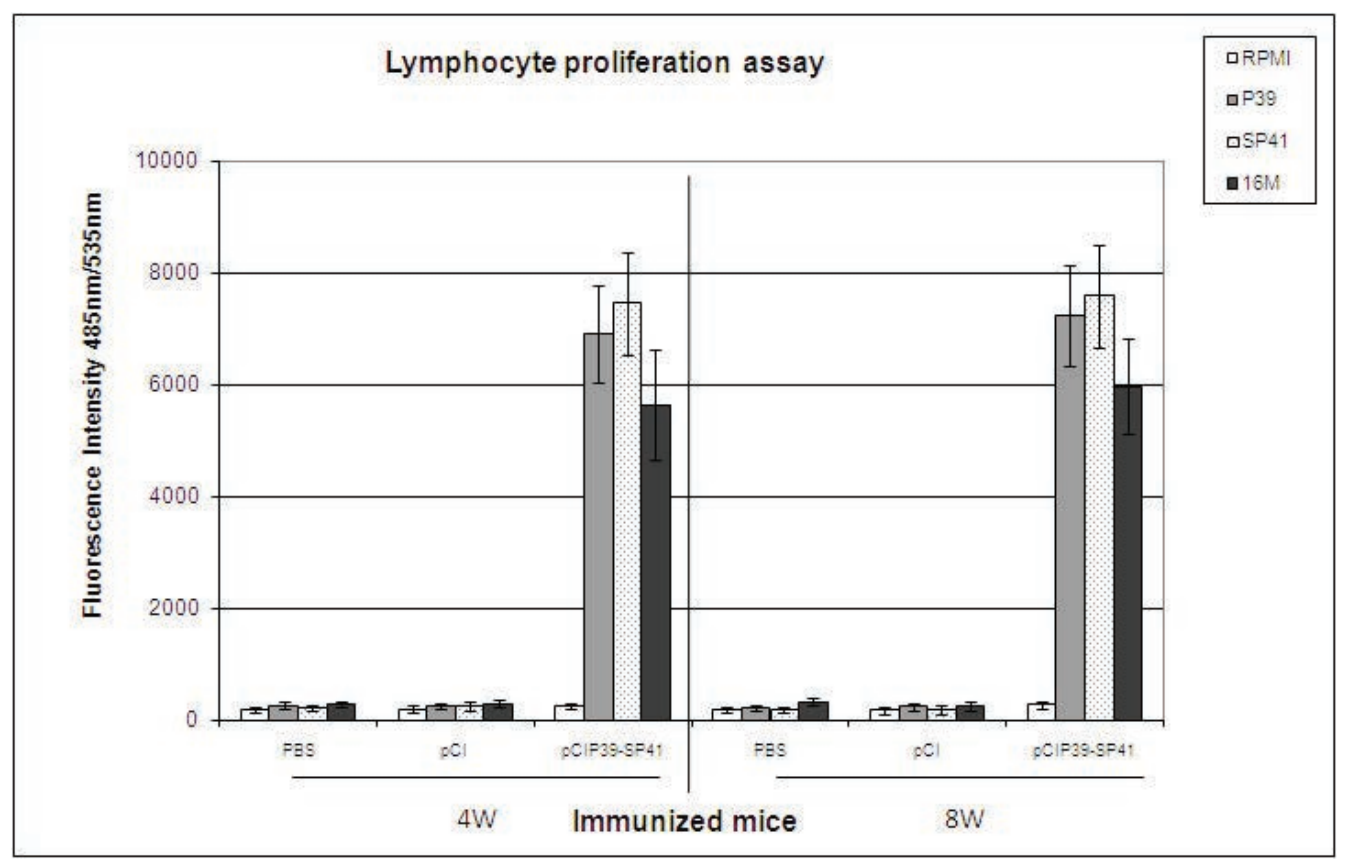

Figure 3. Lymphocyte proliferation assay. BALB/c mice were immunised with PBS, parental plasmid pCI or pCIp39-sp41. At week 4 or 8 after immunisation, Splenocytes from each mouse at $2 \times 10^{5}$ per well were prepared and stimulated in vitro with purified recombinant protein $(1 \mu \mathrm{g} / \mathrm{mL})$ : p39 (gray bars) or sp41 (white-black point bars) and bacteria lysate B. melitensis $16 \mathrm{M}(4 \mu \mathrm{g} / \mathrm{mL})(\mathrm{black}$ bars) as the antigen. Either splenocytes were stimulated without antigen (white bars) as negative control. After $72 \mathrm{~h}$ of culture, $10 \mathrm{~mL}$ of CCK-F working solution were added, $30 \mathrm{~min}$ later, the measure of the fluorescence intensity of each well was determined at 535 $\mathrm{nm}$ (excitation at $485 \mathrm{~nm}$ ) using a fluorescence plate reader. Each sample was assayed in triplicate. Data represent the mean \pm standard deviation (error bars) from the four mice.

Ensayo de proliferación de linfocitos. Ratones BALB/c fueron inmunizados con PBS, plásmido pCI parental o pCIp39-sp41. En la semana 4 u 8 después de la inmunización, esplenocitos de cada ratón a $2 \times 10^{5}$ por pocillo se prepararon y se estimularon in vitro con la proteína recombinante purificada $(1 \mu \mathrm{g} / \mathrm{ml})$ : p39 (barras grises) o sp41 (barras de punto blanco y negro) y las bacterias lisado de B. melitensis $16 \mathrm{M}(4 \mu \mathrm{g} / \mathrm{ml})$ (barras negras) como antígeno. Cualquiera de los esplenocitos se estimularon sin antígeno (barras blancas) como control negativo. Después de $72 \mathrm{~h}$ de cultivo, se añadieron $10 \mathrm{ml}$ de solución de trabajo de CCK-F, 30 minutos más tarde, la medida de la intensidad de fluorescencia de cada pocillo se determinó a $535 \mathrm{~nm}$ (excitación a $485 \mathrm{~nm}$ ) usando un lector de placas de fluorescencia. Cada muestra se ensayó por triplicado. Los datos representan la media \pm desviación estándar (barras de error) de los cuatro ratones.

pCIp39+pCIsp41 genetic vaccine induced significant and specific T-cell proliferation in response to $\mathrm{p} 39$ and sp41 recombinant proteins, comparing with $\mathrm{PBS}$ or pCI groups $(P<0.05)$. In addition, and as a stimulus control, this suggested vaccine induced specific T-cell proliferation in response to RPMI1640 medium. Splenocytes from all experimental groups revealed very similar proliferative responses to ConA mitogen throughout the study (data not shown).

Figure 4 shows the cytokine-producing T-cell profiles from splenocytes of five vaccinated mice per group, after four weeks from the last immunisation of mice. The supernatants from splenocyte cultures of mice vaccinated with pCIp39+pCIsp41 vaccine and stimulated with p39, sp41 proteins or Brucella extract, contained a significantly greater quantity of IFN- $\gamma$ comparing with mice vaccinated with PBS or pCI $(P<0.007)$. In contrast, in vitro stimulation of splenocytes with RPMI1640 medium did not produce any quantity of IFN- $\gamma$ (figure 4).
In addition, splenocytes stimulated with specific antigens could not produce IL-5 in any culture supernatants (data not shown). And also, pCI expressing vector and PBS were elicited the same quantity of CMI.

\section{EFFICACY OF PCIp39 AND PCIsp41 IMMUNISATION IN GENERATING PROTECTIVE IMMUNITY AGAINST $B$. MELITENSIS 16M}

Four weeks after the last immunisation, vaccinated mice were i.p. challenged with $B$. melitensis $16 \mathrm{M}$. Infection severity was determined by counting the bacterial $\mathrm{CFU}$ in the spleen, four and eight weeks post-challenge. Table 2 demonstrated that DNA vaccines produced significantly higher degree of protection comparing with pCI $(P<0.05)$. Whereas, the reciprocal titers in the groups that received DNA vaccines were $1.37-\log$ $(P<0.005)$ to $1.31-\log (P<0.05)$ more elevated comparing with control, 4 and 8 weeks post-challenge, re- 


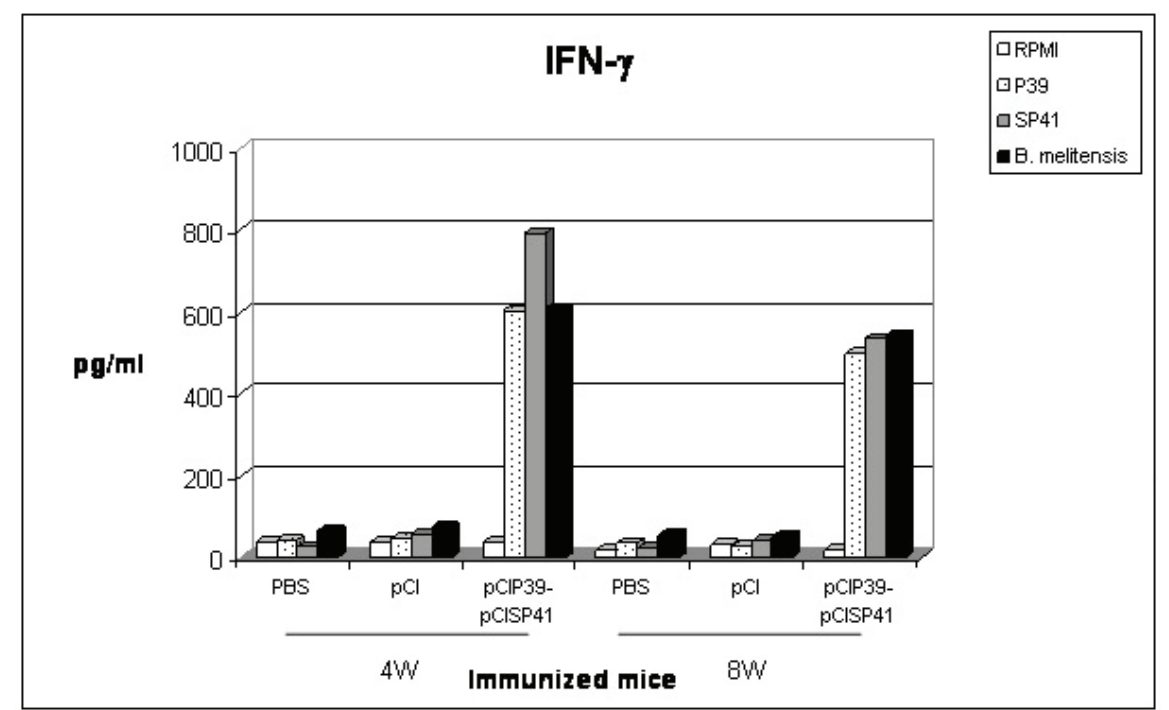

Figure 4. IFN- $\gamma$ production, in vitro, by splenocytes from immunised mice upon stimulation with different antigens. BALB/c mice were immunised with PBS, parental plasmid pCI or pCIp39-sp41. Mice were killed 4 or 8 weeks after the last injection. 2 x $10^{5}$ CFU of splenocytes were isolated and cultured in 96-well plates in triplicate without antigen (RPMI) as negative control, or with purified recombinant protein $(1 \mu \mathrm{g} / \mathrm{mL})$ : p39 or sp41 and bacteria lysate B. melitensis $16 \mathrm{M}(4 \mu \mathrm{g} / \mathrm{mL})$ as the antigen. After $96 \mathrm{~h}$, supernatants were collected and tested for IFN- $\gamma$ production by sandwich ELISA.

La producción de IFN- $\gamma$, in vitro, por esplenocitos de ratones inmunizados tras la estimulación con antígenos diferentes. Ratones BALB/c fueron inmunizados con PBS, plásmido pCI parental o pCIp39-sp41. Los ratones fueron sacrificados 4 u 8 semanas después de la última inyección. 2 x 105 UFC de esplenocitos se aislaron y se cultivaron en placas de 96 pocillos por triplicado y sin antígeno (medio RPMI) como control negativo, o con la proteína recombinante purificada $(1 \mu \mathrm{g} / \mathrm{mL})$ : p39 o sp41 y lisado bacteriano de B. melitensis $16 \mathrm{M}(4 \mu \mathrm{g} / \mathrm{mL})$ como antígeno. Después de 96 h, se recogieron los sobrenadantes y se probaron para la producción de IFN- $\gamma$ mediante ELISA sandwich.

Table 2. Protection of BALB/c mice against challenge with B. melitensis $16 \mathrm{M}$ after immunisation with DNA vaccine coding for $\mathrm{p} 39$ and $\mathrm{sp} 41^{\mathrm{a}}$.

Protección de ratas BALB/c contra desafío con 16M B. melitensis después de la inmunización con la vacuna DNA codificando para p39 y sp41ª .

\begin{tabular}{cccccc}
\hline & Vaccine & $\log _{10}$ CFU of B. melitensis $16 \mathrm{M}$ & \multicolumn{2}{c}{$\log _{10}$ units of protection } \\
\hline Mice group & \multicolumn{5}{c}{ in spleen (mean + SD) } \\
\hline$(\mathrm{n}=4)$ & & $4 \mathrm{w}$ & $8 \mathrm{w}$ & $4 \mathrm{w}$ & $8 \mathrm{w}$ \\
1 & PBS & $5.67 \pm 0.42$ & $5.26 \pm 0.13$ & - & - \\
2 & pCI & $5.71 \pm 0.29$ & $5.36 \pm 0.11$ & - & - \\
3 & pCIp39+pCIsp41 & $4.30 \pm 0.16$ & $3.95 \pm 0.13$ & $1.37^{\mathrm{c}}$ & $1.31^{\mathrm{b}}$ \\
4 & Rev.1 & $3.88 \pm 0.31$ & $2.09 \pm 0.18$ & $1.79^{\mathrm{c}}$ & $3.17^{\mathrm{b}}$ \\
\hline
\end{tabular}

${ }^{a}$ Mice were challenged intraperitoneally with $10^{5} \mathrm{CFU}$ of the last immunisation.

${ }^{\mathrm{b}} P<0.05,{ }^{\mathrm{c}} P<0.005$, (significant) compared to the control group.

spectively. In addition, reciprocal titers of the group that received live $B$. melitensis Rev.1 strain were $1.79-\log$ $(P<0.005)$ to $3.17-\log (P<0.05)$ more elevated comparing with control, 4 and 8 weeks post-challenge, respectively. In contrast, similar results were found in the control group and the group that received pCI.

\section{DISCUSSION}

Vaccination continues to be the most successful procedure for preventing infectious diseases in animals and humans (Srivastava 2003). The development of new generation vaccine systems to prevent brucellosis is nee- 
ded to overcome the disadvantages of the currently used live vaccines; such as, causing abortion in pregnant animals, pathogenicity for humans, and inducing antibodies that interfere with the diagnosis of vaccinated animals (Jacques et al 2007, Grilló et al 2009). B. melitensis Rev.1 vaccine is currently the best vaccine for caprine and ovine brucellosis (Blasco 2010), despite it induces anti-LPS responses making it difficult to distinguish vaccinated from infected animals (Moriyón et al 2004). Thus, the development of a subunit vaccine free of $B$. melitensis LPS would have significant benefits (Ficht et al 2009). Several previously described DNA vaccines against Brucella revealed that divalent vaccines could induce a more intensive humoral and immune response than the univalent vaccine (Luo et al 2006 $\left.6^{\mathrm{a}, \mathrm{b}}\right)$. Luo et al $\left(2006^{\mathrm{b}}\right)$ found that injection with pcDNA3.1-L7/L12-Omp16 divalent DNA vaccine induced high titers of total IgG. In addition, intramuscular injection of plasmid DNA carrying the BAB1_0263 and BAB1_0278 genes (pVF263 and pVF278, respectively) elicited specific humoral immune responses ( $\mathrm{IgG}$ ) in BALB/c mice (Sislema-Egas et al 2012). Our results revealed that the immunisation with divalent DNA vaccine (pCIp39 and pCIsp41) could induce remarkably high titers of total $\mathrm{IgG}$ in BALB/c mice (figure 2).

In mouse model, various candidates have been explored for their value as nucleic acid vaccines against brucellosis providing various levels of specific cellular immune responses. Intramuscular injection of plasmid DNA carrying the BAB1_0278 gene elicited a T-cellproliferative response and induced significant levels of IFN- $\gamma$ upon re-stimulation with recombinant protein (Sislema-Egas et al 2012). Cassataro et al (2007) found that a pcDNABLS induced a strong cellular response against the inserted peptide. In addition, DNA vaccine encoding omp31 gene (pTargeTomp31) elicited a T-cell-proliferative response and induced a strong IFN- $\gamma$ production upon re-stimulation with either the Omp31 antigen or B. melitensis 16M extract (Gupta et al 2007). Whereas, our results demonstrated that immunisation with pCIp39 and pCIsp41 DNA vaccines induced a high T-cell proliferative response (figure 3) and high levels of IFN- $\gamma$ (figure 4), without any detectable level of IL-5 (data not shown), which indicates the induction of Th1 cellular response.

Based on these data, protective efficacy of the pCIp39 and pCIsp41 vaccines against challenge with $B$. melitensis $16 \mathrm{M}$ shown increasing of reciprocal titers to $1.37-\log$ and $1.31-\log , 4$ and 8 weeks after the last immunisation, respectively.

The survival time of $B$. melitensis $16 \mathrm{M}$ within mice is longer than Rev.1 because it is capable of invading and residing in professional phagocytes, such as macrophages, as well as non-phagocytic cells (Guo et al 2012). In addition, virulent Brucella organisms can replicate within the phagosome, this mechanism is associated with the ability to inhibit phagolysosome fusion, degranulation and activation of the myeloperoxidase-halide system, and the production of tumor necrosis factor (Eskra et al 2012). Because live smooth attenuated, Rev.1 strain is unable to prevent such fusion, and then it is destroyed by the lysosomal contents (Guilloteau et al 2006).

There are more $\mathrm{T}$ cell epitopes in the divalent than in univalent DNA vaccine. It is also possible to create multivalent DNA vaccines that might be able to stimulate immunity against a range of pathogens (Yang et al 2005). The i.m. pathway is the most common route of DNA administration. In this study, we found that i.m. injection of a DNA vector containing the DNA insert of Brucella p39 and sp41 was able to generate a level of protection higher than DNA vaccine encoding the L7L12 (Kurar and Splitter 1997), SOD (Oñate et al 2003), p39 (Al-Mariri et al 2001 ${ }^{\mathrm{b}}$ ) or BAB1_0278 (SislemaEgas et al 2012), which induced a moderate protection in BALB/c mice challenged with Brucella compared to that observed in positive control mice vaccinated with live vaccine S19. In contrast, Cassataro et al (2007) found that the vaccination of $\mathrm{BALB} / \mathrm{c}$ mice with the DNA vaccine coding for the chimera BLSOmp31 (pCIBLSOmp31) provided similar protection as Rev.1 against B. melitensis. Moreover, Luo et al $\left(2006^{\mathrm{b}}\right)$ found that divalent DNA vaccine encoding both the $L 7 / L 12$ and ompl6 genes elicit protective immunity against $B$. abortus in BALB/c mice. In addition, Yu et al (2007) showed that combined DNA vaccine encoding bcsp31, sod, and $L 7 / L 12$ confers high protection against $B$. abortus 2308.

Despite pCIp39+pCIsp41 vaccine was not effective 8 weeks post-infection, we remain confident of the potential of p39 and sp41 antigens. More investigations by using new formulations of the pCIp39+pCIsp41 plasmid (e.g., adding $\mathrm{CpG}$ ODN as adjuvant), or a live delivery vector, might offers the opportunity to increase the potency of this candidate vaccine, which is currently under investigation in our laboratory.

In conclusion, we have shown that inoculation of plasmid DNA containing the pCIp39 and pCIsp41 genes leads to the elicitation of both humoral and cellular responses of Th-1 type. A significant finding of this study was that the protection achieved with pCIp39 and pCIsp41 was comparable to that induced by the live Rev.1 vaccine 4 weeks post-infection, but it was less 8 weeks post-infection. Finally, plasmid DNA vaccination may be a successful alternative method for conferring protection against Brucella.

\section{ACKNOWLEDGEMENTS}

The authors would like to thank the Director General of AECS, and the head of the Molecular Biology and Biotechnology Department for their support. The authors would also like to thank Dr. M. Safi for his critical reading of this manuscript. 


\section{REFERENCES}

Al-Mariri A, A Tibor, P Mertens, X DeBolle, P Michel, J Godefroid, K Walravens, J-J Letesson. 2001ª Protection of BALB/c mice against Brucella abortus 544 challenge by vaccination with Bacterioferritin or $\mathrm{p} 39$ recombinant proteins with $\mathrm{CpG}$ Oligodeoxynucleotides as adjuvant. Infect Immun 69, 4816-4822.

Al-Mariri A, A Tibor, P Mertens, X DeBolle, P Michel, J Godefroid, K Walravens, J-J Letesson. 2001 ${ }^{\mathrm{b}}$. Induction of immune response in $\mathrm{BALB} / \mathrm{c}$ mice with a DNA vaccine encoding bacterioferritin or $\mathrm{p} 39$ of Brucella spp. Infect Immun 69, 6264-6270.

Al-Mariri A, A Tibor, P Lestrate, P Mertens, X DeBolle, J-J Letesson. 2002. Yersinia enterocolitica as a vehicle for a Naked DNA vaccine encoding Brucella abortus bacterioferritin or p39 antigen. Infect Immun 70, 1915-1923.

Al-Mariri A. 2010. Protection of BALB/c mice against Brucella melitensis $16 \mathrm{M}$ infection induced by vaccination with live Escherchia coli expression Brucella p39 protein. Vaccine 28, 1766-1770.

Banai M. 2002. Control of small ruminant brucellosis by use of Brucella melitensis Rev.1 vaccine: laboratory aspects and field observations. Vet Microbiol 20, 497-519.

Blasco JM. 1997. A review of the use of B. melitensis Rev.1 vaccine in adult sheep and goats. Prev Vet Med 31, 275-283.

Blasco JM. 2010. Control and eradication strategies for Brucella melitensis infection in sheep and goats. Prilozi 31, 145-165.

Cassataro J, KA Pasquevich, SM Estein, DA Laplagne, A Zwerdling, S de la Barrera, R Bowden, CA Fossati, GH Giambartolomei, FA Goldbaum. 2007. A DNA vaccine coding for the chimera BLSOmp31 induced a better degree of protection against $B$. ovis and a similar degree of protection against B. melitensis than Rev.1 vaccination. Vaccine 10, 5958-5967.

Castañeda-Roldán El, S Ouahrani-Bettache, Z Saldaña, F Avelino, MA Rendón, J Dornand, JA Girón. 2006. Characterization of sp41, a surface protein of Brucella associated with adherence and invasion of host epithelial cells. Cell Microbiol 8, 1877-1887.

Coban C, S Koyama, F Takeshita, S Akira, KJ Ishii. 2008. Molecular and cellular mechanisms of DNA vaccines. Hum Vaccin 4, 453-456.

Davis DS, PH Elzer. 2002. Brucella vaccine in wildlife. Vet Microbiol 90, 533-544.

DelVecchio VG, T Alefantis, RA Ugalde, D Comerci, MI Marchesini, A Khan, W Lubitz, CV Mujer. 2006. Identification of protein candidates for developing bacterial ghost vaccines against Brucella. Methods Biochem Anal 49, 363-377.

Denoël PA, TK Vo, A Tibor, VE Weynants, JM Trunde, G Dubray, JN Limet, JJ Letesson. 1997ª Characterization, occurrence, and molecular cloning of a 39-kilodalton Brucella abortus cytoplasmic protein immunodominant in cattle. Infect Immun 65, 495-502.

Denoël PA, TK Vo, VE Weynants, A Tibor, D Gilson, MS Zyg-

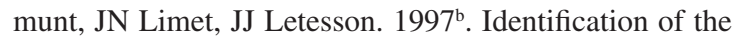
major T-cell antigens present in the Brucella melitensis B115 protein preparation, Brucellergene OCB. J Med Microbiol 46, 801-806.
Donnelly JJ, JB Ulmer, JW Shiver, MA Liu. 1997. DNA vaccines. Annu Rev Immunol 15, 617-648.

Eskra L, J Covert, J Glasner, G Splitter. 2012. Differential expression of iron acquisition genes by Brucella melitensis and Brucella canis during macrophage infection. PLoS One 7, e31747.

Ficht TA, MM Kahl-McDonagh, AM Arenas-Gamboa, AC Rice-Ficht. 2009. Brucellosis: the case for live, attenuated vaccines. Vaccine 5;27 Suppl 4, D40-43.

Glynn MK, TV Lynn. 2008. Brucellosis. J Am Vet Med Assoc 15, 900-908.

Gorvel JP. 2008. Brucella: a Mr "Hide" converted into Dr Jekyll. Microbes Infect 10, 1010-1013.

Grilló MJ, CM Marín, M Barberán, MJ de Miguel, K Laroucau, I Jacques, JM Blasco. 2009. Efficacy of bp26 and bp26/ omp31 B. melitensis Rev.1 deletion mutants against Brucella ovis in rams. Vaccine 27, 187-191.

Guilloteau LA, K Laroucau, M Olivier, MJ Grillo, CM Marin, JM Verger, JM Blasco. 2006. Residual virulence and immunogenicity of CGV26 and CGV2631 B. melitensis Rev. 1 deletion mutant strains in sheep after subcutaneous or conjunctival vaccination. Vaccine 24, 3461-3468.

Guo F, H Zhang, C Chen, S Hu, Y Wang, J Qiao, Y Ren, K Zhang, Y Wang, G Du. 2012. Autophagy favors Brucella melitensis survival in infected macrophages. Cell Mol Biol Lett 17, 249-257.

Gupta VK, PK Rout, VS Vihan. 2007. Induction of immune response in mice with a DNA vaccine encoding outer membrane protein (omp31) of Brucella melitensis 16M. Res Vet Sci 82, 305-313.

Higgins D, JD Marshall, P Traquina, G Van Nest, BD Livingston. 2007. Immunostimulatory DNA as a vaccine adjuvant. Expert Rev Vaccines 6, 747-759.

Jacques I, JM Verger, K Laroucau, M Grayon, N Vizcaino, A Peix, F Cortade, F Carreras, LA Guilloteau. 2007. Immunological responses and protective efficacy against Brucella melitensis induced by bp26 and omp31 B. melitensis Rev.1 deletion mutants in sheep. Vaccine 25, 794-805.

Kenison DC, TH Elsasser, R Fayer. 1990. Radioimmunoassay for bovine tumor necrosis factor: concentrations and circulating molecular forms in bovine plasma. J Immunoassay $11,177-198$.

Kurar E, GA Splitter. 1997. Nucleic acid vaccination of Brucella abortus ribosomal L7/L12 gene elicits immune response. Vaccine 15, 1851-1857.

Kutzler MA, DB Weiner. 2008. DNA vaccines: ready for prime time? Nat Rev Genet 9, 776-788.

Luo DY, P Li, L Xing, GY Zhao, W Shi, SL Zhang, XL Wang.

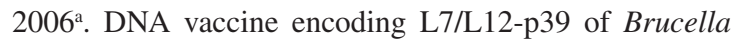
abortus induces protective immunity in $\mathrm{BALB} / \mathrm{c}$ mice. Chinese Medical J 119, 331-334.

Luo D, B Ni, P Li, W Shi, S Zhang, Y Han, L Mao, Y He, Y Wu, X Wang. 2006 ${ }^{\text {b }}$. Protective immunity elicited by a divalent DNA vaccine encoding both the $L 7 / L 12$ and Omp 16 genes of Brucella abortus in BALB/c mice. Infect Immun 74, 2734-2741.

Moriyón I, MJ Grilló, D Monreal, D González, C Marín, I López-Goñi, RC Mainar-Jaime, E Moreno, JM Blasco. 2004. Rough vaccines in animal brucellosis: structural and genetic basis and present status. Vet Res 35, 1-38.

Muñoz-Montesino C, E Andrews, R Rivers, A González-Smith, 
G Moraga-Cid, H Folch, S Céspedes, AA Oñate. 2004. Intraspleen delivery of a DNA vaccine coding for superoxide dismutase (SOD) of Brucella abortus induces SOD-specific CD4+ and CD8+ T cells. Infect Immun 72, 2081-2087.

Muñoz PM, MJ de Miguel, MJ Grilló, CM Marín, M Barberán, JM Blasco. 2008. Immunopathological responses and kinetics of Brucella melitensis Rev 1 infection after subcutaneous or conjunctival vaccination in rams. Vaccine 26, 2562-2569.

Oñate AA, S Céspedes, A Cabrera, R Rivers, A González, C Muñoz, H Folch, E Andrews. 2003. A DNA vaccine encoding $\mathrm{Cu}-\mathrm{Zn}$ superoxide dismutase of Brucella abortus induces protective immunity in BALB/c mice. Infect Immun 71, 4857-4861.

Seleem MN, SM Boyle, N Sriranganathan. 2010. Brucellosis: a re-emerging zoonosis. Vet Microbiol 27, 392-398.

Sislema-Egas F, S Céspedes, P Fernández, A Retamal-Díaz, D Sáez, A Oñate. 2012. Evaluation of protective effect of DNA vaccines encoding the BAB1_0263 and BAB1_0278 open reading frames of Brucella abortus in BALB/c mice. Vaccine 30, 7286-7291.

Srivastava Singh MI. 2003. Advances in vaccine adjuvants for infectious diseases. Curr HIV Res 1, 309-320.

Velikovsky CA, J Cassataro, GH Giambartolomei, FA Goldbaum, S Estein, RA Bodwen, L Bruno, CA Fossati, M
Spitz. 2002. A DNA vaccine encoding lumazine synthase from Brucella abortus induce protective immunity in BALB/c mice. Infect Immun 70, 2507-2511.

Vemulapalli R, S Cravero, CL Calvert, TE Toth, N Sriranganathan, SM Boyle, OL Rossetti, GG Schurig. 2000. Characterization of specific immune responses of mice inoculated with recombinant vaccinia virus expressing an 18-kilodalton outer membrane protein of Brucella abortus. Clin Diagn Lab Immunol 7, 114-118.

Weeratna RD, T Wu, SM Efler, L Zhang, HL Davis. 2001. Designing gene therapy vectors: avoiding immune responses by using tissue-specific promoters. Gene Therapy 8 , 1872-1878.

Yang X, M Hudson, N Walters, RF Bargatze, DW Pascual. 2005. Selection of protective epitopes for Brucella melitensis by DNA vaccination. Infect Immun 73, 7297-7303.

Yingst S, DL Hoover. 2003. T cell immunity to brucellosis. Crit Rev Microbiol 29, 313-331.

Yu DH, XD Hu, H Cai. 2007. A combined DNA vaccine encoding BCSP31, SOD, and L7/L12 confers high protection against Brucella abortus 2308 by inducing specific CTL responses. DNA and cell biology. DNA Cell Biol 26, 435443.

Zhan Y, C Cheers. 1993. Endogenous gamma interferon mediates resistance to Brucella abortus infection. Infect Immun 61, 4899-4901. 